\title{
EDUCATION 4.0: DEFINING THE TEACHER, THE STUDENT, AND THE SCHOOL MANAGER ASPECTS OF THE REVOLUTION
}

\author{
Beyza HIMMETOGLU \\ ORCID: 0000-0003-0757-232X \\ Faculty of Education Anadolu University \\ Eskisehir, TURKEY \\ Damla AYDUG \\ ORCID: 0000-0001- 8348-5098 \\ Faculty of Education \\ Anadolu University \\ Eskisehir, TURKEY \\ Dr. Coskun BAYRAK \\ ORCID: 0000-0001-5524-5206 \\ Faculty of Education \\ Anadolu University \\ Eskisehir, TURKEY
}

Received: 19/09/2019 Accepted: 12/02/2020

\begin{abstract}
In this research, it is aimed to determine the school managers', teachers' and students' characteristics of Education 4.0 according to opinions of educational experts. The study, which is a qualitative one, was designed by using basic qualitative research model. Participants of the study consisted of 10 faculty members, selected with snowball sampling method. Data of the study was collected via semi-structured interview form. To analyze data, content analysis technique will be used. It is expected to operationalize Education 4.0 revolution in education system for the case of Turkish Education System. According to findings, open access, individualized education, mental transformation, integration of digital technologies to education, seamless learning environments, lifelong learning, exploratory education and multidisciplinary education are the main components defining Education 4.0. It was found that the main qualities expected from the students of Education 4.0 are cooperation-communication skills, technological skills, learning skills and personal characteristics. The main qualifications expected from the teachers of Education 4.0 are technological skills, guidance skills, lifelong learning skills and personal characteristics. Lastly, the main qualifications expected from the school managers of Education 4.0 are guidance skills, technological skills, learning skills and technical skills.
\end{abstract}

Keywords: Education 4.0, teacher, student, school manager

\section{INTRODUCTION}

The industrial revolution has led to rapid and radical changes in many aspects of social life such as work, education, management and daily life (Blinder, 2006, p.116). Developments brought by Industrial Revolution have gone through four phases from the mid-18th century until the beginning of 21. Century (Bloem et al., 2014, p.11; World Economic Forum, 2017, p.7). The first Industrial Revolution is called "Machine Age", the second one is "Electricity Age", the third one is "Electronics Age" and the fourth one is "Internet Age" (Peters, 2017, p.34). The 2010s are the years of fourth phase of Industrial Revolution which witness the fastest changes and transformations ever. The fourth phase of Industrial Revolution points to an innovational period which covers cyber-physical systems (Bloem et al., 2014, p.11; Peters, 2017, p.36). The fourth industrial revolutions developing with cyber-physical systems were first suggested by a working group 
which consists of the representatives of Academy, industry, and politics in Germany in 2011 with the name of Industry 4.0 (Hermann, Pentek \& Otto, 2016, p.3929). The most crucial development lead to Industry 4.0 is the usage of internet in industrial fields (Drath \& Horch, 2014, p.57). Cyber-physical systems, which have contributed to development of Industry 4.0, point out the Technologies which increase and enhance human capacity by being a part of daily life (Ballantyne, Wong \& Morgan, 2017, p.2). Cyber-physical systems make the concept of "internet of things", which enables "things" or "objects" working connectedly, a crucial concept for Industry 4.0 (Hermann, Pentek \& Otto, 2016, p.3929). One of the characteristics of Industry 4.0 is the highest change pace ever (World Economic Forum, 2017, p.7) and the other one is the difficulty of predicting the effects of these changes (Ballantyne, Wong \& Morgan, 2017, p.2). Accordingly, it is possible the changes brought by Industry 4.0 will make change necessary for not only production sector but also many aspects of social life.

Small-scale and large-scale changes that occurred during Industrial Revolution period have led to changes that effect almost every aspect of life. As new production features have changed workforce competencies economy demands, social life has obliged to evolve accordingly. Moravec (2013) approaches this situation as Society 1.0, Society 2.0, Society 3.0 correspondingly with Industry 1.0, Industry 2.0 and Industry 3.0. One of the sub-systems in society which was affected seriously from these transformations is education. Accordingly, with changes in the production process and the reflections of these changes on social life, content and concept and content of education have gained new meanings. Some authors have called these transformations education has passed or is expected to pass through as Education 1.0, 2.0, 3.0 and 4.0 (Harkins, 2008; Moravec, 2013). Education 1.0 is a kind of education that meets the needs of agricultural society. Knowledge was used to be transferred from teacher to student and students focuses on teacher's explanations. Education 2.0 is a kind of education system which meets the needs of industrial society. Learning process is focused on acquiring technologies that will be utilized in work life. Education 3.0 has evolved education to meet the needs of society by taking advantage of technology. Lastly, Education 4.0, developed at the beginnings of 21 st century is expected to meet needs of innovation age. Students are expected to produce and adapt new Technologies which will contribute development of societies in this process (Puncreobutr, 2016, p.93-94). Education 1.0 is conceptualized as "download education", Education 2.0 as "open access education, Education 3.0 as "knowledge-producing education" and lastly Education 4.0 as "innovation producing education" (Harkins, 2008; Moravec, 2008).

With Education 4.0, Harkins (2008) calls it an innovation producing process, concepts like meaning, technology, teaching, schools, and teacher have been redefined. Accordingly, meaning is built via innovationfocused practices facilitated by individuals or teams. Technology changes continuously with inputs brought by students who have a crucial role in innovation producing process. Teaching is enhanced by positive innovation feedback loops. Teaching, at the same time, gains a continuous occurrence at each moment of daily life, learning life and work life. Schools are situated in human bodies which are globally networked. This position transforms schools an innovative construct which replaces with classroom by continuously evolving. Teachers of Education 4.0 are defined as everybody, everywhere and seen as innovation producing sources.

Education 4.0 can be seen as new paradigm which reinterprets the concepts as learning, student, teacher and school according to needs of Industry 4.0. One of the examples of innovative teaching and learning practices as a part of Educations 4.0 is flipped classroom model. In flipped classrooms, students can investigate lessonrelated digital sources such as videos, presentations materials, e-materials out of school and they can acquire the knowledge they need out of traditional classrooms. So, students can utilize classroom time for activities such as discussion, analysis and problem solving (Youngkin, 2014, p.368). Flipped classrooms can be accepted as a blended learning process since this model utilizes online learning materials while transforming traditional classrooms and enhances education process with these materials (Garrison \& Kanuka, 2004, p.96; Gogebakan-Yildiz, Kiyici \& Altintas, 2016, p.187). So, flipped classroom is a teaching-learning model which makes students responsible for their own learning, is practice-based, gives students individualized education opportunities and gives the opportunity of learning anywhere and anytime. Therefore, it can be said that flipped classroom model is coherent with qualifications of Education 4.0. Flipped classrooms which give the opportunity of blended learning can be evaluated as a mode developed example of Education 3.0 and distance education practices. During Education 3.0 process issues like how to integrate education and 
technology, how to include technology in present educational programs which are already very crowded and intense or how to overcome inconsistency between schooling and information Technologies were discussed (Ballantyne, Wong \& Morgan, 2017, p.4; Collins \& Halverson, 2010, p.19; Sendov, 1987, p.193). However, answer of question as which educational and managerial practices are needed for education 4.0 is so abstract and beyond satisfactory.

Education 4.0 can be seen as a new paradigm which reinterprets the concepts like learning, student, teacher and school according to needs of Industry 4.0. One of the examples of innovative teaching and learning practices as a part of Educations 4.0 is the flipped classroom model. In flipped classrooms, students can investigate lesson-related digital sources such as videos, presentations materials, e-materials out of school and they can acquire the knowledge they need out of traditional classrooms. So, students can utilize classroom time for activities such as discussion, analysis, and problem solving (Youngkin, 2014, p.368). Flipped classrooms can be accepted as a blended learning process since this model utilizes online learning materials while transforming traditional classrooms and enhances education process with these materials (Garrison \& Kanuka, 2004, p.96; Gogebakan-Yildiz, Kiyici \& Altintas, 2016, p.187). So, flipped classroom is a teaching-learning model which makes students responsible for their learning, is practice-based, gives students individualized education opportunities and gives the opportunity of learning anywhere and anytime. Therefore, it can be said that flipped classroom model is coherent with qualifications of Education 4.0. Flipped classrooms which give the opportunity of blended learning can be evaluated as a mode developed example of Education 3.0 and distance education practices. During Education 3.0 process issues like how to integrate education and technology, how to include technology in present educational programs which are already very crowded and intense or how to overcome inconsistency between schooling and information Technologies were discussed (Ballantyne, Wong \& Morgan, 2017, p.4; Collins \& Halverson, 2010, p.19; Sendov, 1987, p.193). However, answer of question as to which educational and managerial practices are needed for education 4.0 is so abstract and beyond satisfactory.

Education is one of the most important tools in providing human skills needed as a result of economic, social and technological transformations of the 21 st century. In this context, issues as Education 4.0, which emphasizes an education that will raise the producers and users of Industry 4.0, innovation in education and the acquisition of innovation skills through education are discussed. One of the topics emphasized within the scope of education that will raise individuals of Industry 4.0 is 21 st-century skills. 21 st-century skills are classified under various titles such as individual skills, interpersonal skills, life skills, applied skills, labor skills, non-cognitive skills (McComas, 2014, p.1), learning and innovation skills, knowledge, media and technology skills, life and career skills (P21, 2009). 21st-century skills, which emphasize innovation and learning skills as well as social, affective skills, have similar characteristics with educational content aiming innovation producing. However, studies and discussions about which educational and managerial processes and practices should be implemented to equip students with those skills are still going on.

21 st-century skills, which are aimed to be gained through education, and the concept of innovation that has been discussed in the field of education since the mid-2000s, reflect the transformations expected from education by Industry 4.0. These transformations clarify the content of Education 4.0 and lead to redefining the educational concepts, processes, and practices. The formation of a theoretical structure about education 4.0 for putting it into practice can be evaluated as an important requirement for the transition of societies to Industry 4.0 and for their economic growth and social development. However, there are very few studies which discuss the theoretical structure of Education 4.0 both in Turkish (Yildiz-Aybek, 2017) and in foreign literature (Harkins, 2008; Peters, 2017; Puncreobutr, 2016; Wallner \& Wagner, 2016). Also, these very studies take Education 4.0 at a very abstract and at only theoretical level. However, taking into consideration that the subjective, cultural and economic structure of the societies and the unique characteristics of their educational systems, it is thought that the content and characteristics of Education 4.0 are needed to be operationalized to direct the implementation. Thus, concrete implementation proposals would be developed to facilitate the transition to Education 4.0 in accordance with the structure and functioning of the Turkish education system. In addition, determining characteristics of Education 4.0 would contribute to the related literature. In this context, it is aimed to determine the characteristics of school manager, teacher and student aspects of Education 4.0 according to the opinions of experts on educational sciences in this study. 


\section{METHOD}

\section{Research Design}

Qualitative research method was used in the study which examined the reflections of Education 4.0 concept in education. Qualitative research process is utilized for drawing a detailed and realistic picture of phenomena or events by using qualitative data collection methods such as observation, interview and document analysis (Yildirim \& Simsek, 2011, p.39). Basic qualitative research design, one of the qualitative research models, was used in the study. The aim of basic qualitative research, which is the most widely used qualitative research design in education, is to examine how individuals interpret their experiences, how they build their perceptions of the world and what meanings they attach to these experiences (Merriam, 2009, p.23). In this study, it was decided that the basic qualitative research design was the most appropriate design since it was examined how faculty members who are experts in the field of education make sense of the concept of Education 4.0.

\section{Participants}

The study group of the research consists of 10 faculty members working in Anadolu University Faculty of Education and Faculty of Open Education in the 2019-2020 academic year. To form the study group, snowball sampling method was used. Snowball sampling is an effective sampling method to reach critical situations or people from whom more detailed information can be obtained (Patton, 2014, p.237). In this research, participant faculty members were selected as participants by snowball sampling method to reach individuals who are have prior knowledge about Education 4.0, a relatively new concept for education world. The study group consisted of 10 faculty members, 5 of whom work in the Educational Sciences Department of Faculty of Education and 5 of whom work in the Distance Education Department of the Faculty of Open Education. The ages of the faculty members in the study group are between 29 and 59; seniority of them varies between 2 and 20 years. 3 of the faculty members are women and 7 of them are men. 2 of the faculty members are professors, 1 of them is an associate professor doctors, 4 of them are assistant professor doctors, 1 of them is a lecturer doctor and 2 of them are research assistants.

\section{Data Collection and Analysis}

Data of the study was obtained through a semi-structured interview form. Semi-structured interview is a very useful data collection tool because of structured enough to emphasize certain aspects of the research problem and flexible enough to allow participants to present new meanings for the study topic (Galletta, 2013, p.1-2). In this study, Education 4.0 at schools was examined in terms of the human capital aspect and so the interview form was structured accordingly. During the preparation of the data collection tool, literature was reviewed in detail on Education 4.0. After the literature review, the draft interview form consisted of 5 open-ended questions and probes. The draft form was rearranged with respect to the expert opinions received from two faculty members in the Department of Educational Administration. Semistructured interview questions formulated with expert opinions are as follow:

1. How do you define Education 4.0?

2. How do you define the teacher of Education 4.0?

3. How do you define the student of Education 4.0?

4. How do you define the school manager of Education 4.0?

Before the interviews, voluntary faculty members were called to arrange an appointment. Researchers introduced themselves and the purpose of the research to the participants. Questions were asked about the demographic characteristics of the participants. Then, researchers asked open-ended questions in the data collection tool to participants. The interviews lasted between 25- 35 minutes. In order to obtain detailed information about the questions, interviews were supported by probe questions.

In the analysis of research data, content analysis technique was used. Content analysis is a systematic and renewable technique in which some words of a text are summarized in smaller content categories as a result of 
coding based on certain rules (Buyukozturk et al. 2011, p.269). According to Patton (2014, p.453), content analysis is any qualitative data reduction and interpretation attempt to determine the basic consistencies and meanings in a dense qualitative material. Research data were analyzed using NVivo 10 data analysis program. The data of the study were analyzed by two different researchers. Analyses were compared until reaching consensus between two researchers.

\section{Credibility, Applicability, Consistency and Limitations of the Study}

Qualitative research, because of its nature and purpose, is different from quantitative research. So, the criteria used to determine the value and usefulness of are different from the ones used in quantitative research (Krefting, 1991, p.214). In quantitative researches, the criteria which make the study scientific are called as validity and reliability. However, since qualitative research focuses on describing a unique case holistically instead of generalizing the results, the concepts of truth value, applicability and consistency are used in it instead of validity and reliability (Krefting, 1991, p.217).

In this study, to increase truth value of this study, some strategies were used such as making intensive and in-depth face to face interviews with participants, reporting findings in detail, explaining how the results were interpreted and member-check. Besides, a detailed literature review was conducted to prepare interview questions and experts were consulted on these questions to provide truth value of the study. Other precautions taken for truth value were making appointments with participants and giving them information about the study before interviews. To make this study applicable, strategies like making detailed explanations on how the interviews were conducted, how the data were obtained and recorded, how the results were combined etc. Therefore, it was tried to give useful information for researchers who will conduct similar researchers. Also, to provide consistency, analyses were made by two independent researchers and the consistency coefficient of their analysis were calculated according to formula suggested by Miles and Huberman (1994, s.64) was used. So, consistency of the findings was found as .86.

The most important limitation of this study is that participants were chosen among experts working at Faculty of Education and Faculty of Open Education since the Education 4.0 is relatively new subject and only few people have knowledge on it. So, to emphasize technological and pedagogical sides of the subject together, participants were limited with these two faculties' members. Other limitations are about studying with small participants and choosing the participants from mentioned faculties of the same university. These limitations are from the nature of qualitative studies which are generally time consuming and costly. The factors such as needed time, cost and effort made researchers to study with only 10 faculty members of only one university.

\section{FINDINGS}

The findings of the study were organized under four titles in line with the sub-questions of the research. The findings were investigated with respect to the views of the faculty members about the basic characteristics of Education 4.0 and the qualifications expected from the student of Education 4.0, the qualifications expected from the teacher of Education 4.0, and the qualifications expected from the school manager of Education 4.0 .

\section{Basic Characteristics of Education 4.0}

The first sub-question of the study is about the views of faculty members about the basic characteristics of Education 4.0. To get findings for first sub-question, analyses were conducted in line with the answers given by Educational Sciences and Distance Education experts to the interview questions. The analysis results were presented in Figure 1. 


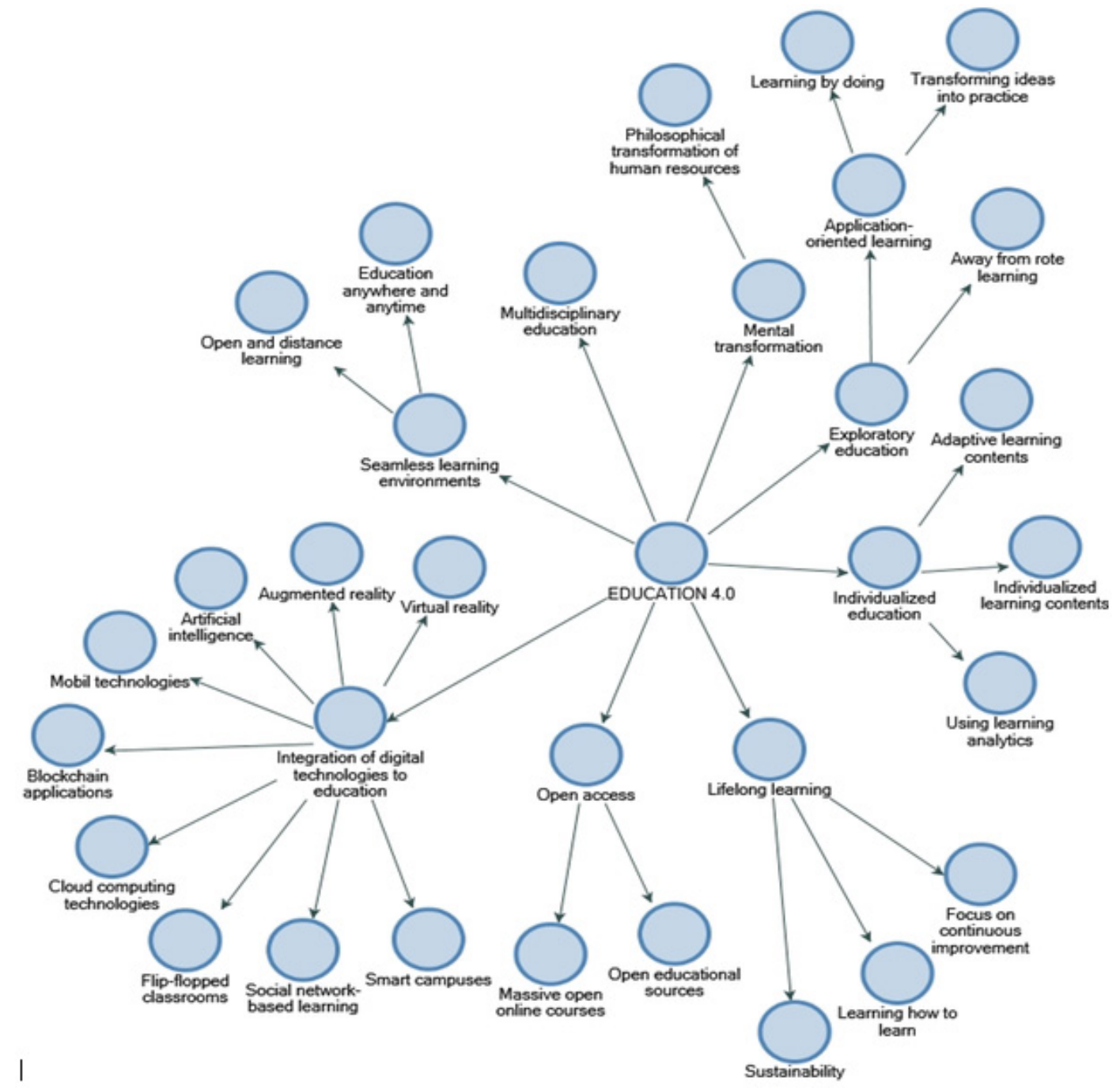

Figure 1. Basic characteristics of Education 4.0

As seen in Figure 1, according to the opinions of the faculty members, the main components which characterize Education 4.0 are open access, individualized education, mental transformation, integration of digital technologies to education, seamless learning environments, lifelong learning, exploratory education and multidisciplinary education. Within the scope of open access, open educational resources and mass open online courses are given as examples. Within the context of individualized education, faculty members mentioned the preparation of individualized learning contents, creating adaptive learning environments and the usage of learning analytics. Within the scope of mental transformation, participants emphasized necessity of philosophical transformation of human resources. Within the scope of the integration of digital technologies to education, suggestions were made for the use of technological innovations such as smart campuses, augmented reality, cloud information technologies and virtual reality in education. Seamless learning environments were explained with learning going out of the classroom and learning anywhere and anytime. Lifelong learning, one of the most focused themes in the context of Education 4.0, was associated with the learning how to learn, sustainability and continuous development. Finally, exploratory education was explained with education away from rote learning and application-oriented learning activities. Some of the statements used by faculty members for the basic characteristics of Education 4.0 are as below:

"People are saying that 65\% of the jobs we know today will be useless in the near future. In this regard we don't know what kind of qualifications future jobs will demand. It is impossible for us to equip students with qualifications which will prepare them for the jobs of future. So, lifelong learning is crucial and necessary. Sustainability and personal development are also crucial for Education 
4.0. Personal development covers providing individualized learning opportunities students to learn accordingly with their own interest and learning pace." (FM-1)

"Lots of people focus on this side... The most problematic part of the investments is that everything is technology based. But the instrument is changing, environment and media are changing... To say simply, you introduce a Web 2.0 instrument but it doesn't exist 2 years later or what are you doing... An application is put into service with lots of free features for marketing then 1 year later you see that all of these features are sold with a charge. So, we need to provide mental transformation so what I understand from Education 4.0 is acquiring lifelong learning skills." (FM-3)

"Education 4.0 takes the learning environments out of the classroom because it says that learning can be everywhere and anyway. Technologies, especially communication technologies which are with us all the time help us to learn at any time. So, learning becomes information-based rather than memorization because you can do it anytime and anywhere. Briefly, learning in Education 4.0 gets out of classrooms in formal education settings. So, we should raise people adapting themselves to this new age, learning should not be based on only one discipline, but on more discipline. People of this age should be able to see multidisciplinary people of this era." (FM-2)

"I think individualized learning environments will be very important. Because each individual has different needs, different characteristics and different requirements. We are not able to provide an education that meets these requirements yet. In other words, we educate everyone in the same way. The student may be interested in a very different field. Helshe cannot be very productive by going through the same education everyone takes. For this reason, a new concept called adaptive learning systems, meaning adaptable to the skills of students have emerged." (FM-5)

\section{The Qualifications Expected from the Student of Education 4.0}

The second sub-question of the research is related to the views of faculty members about the qualifications expected from the student of Education 4.0. The findings obtained from analysis are summarized in Table 2.

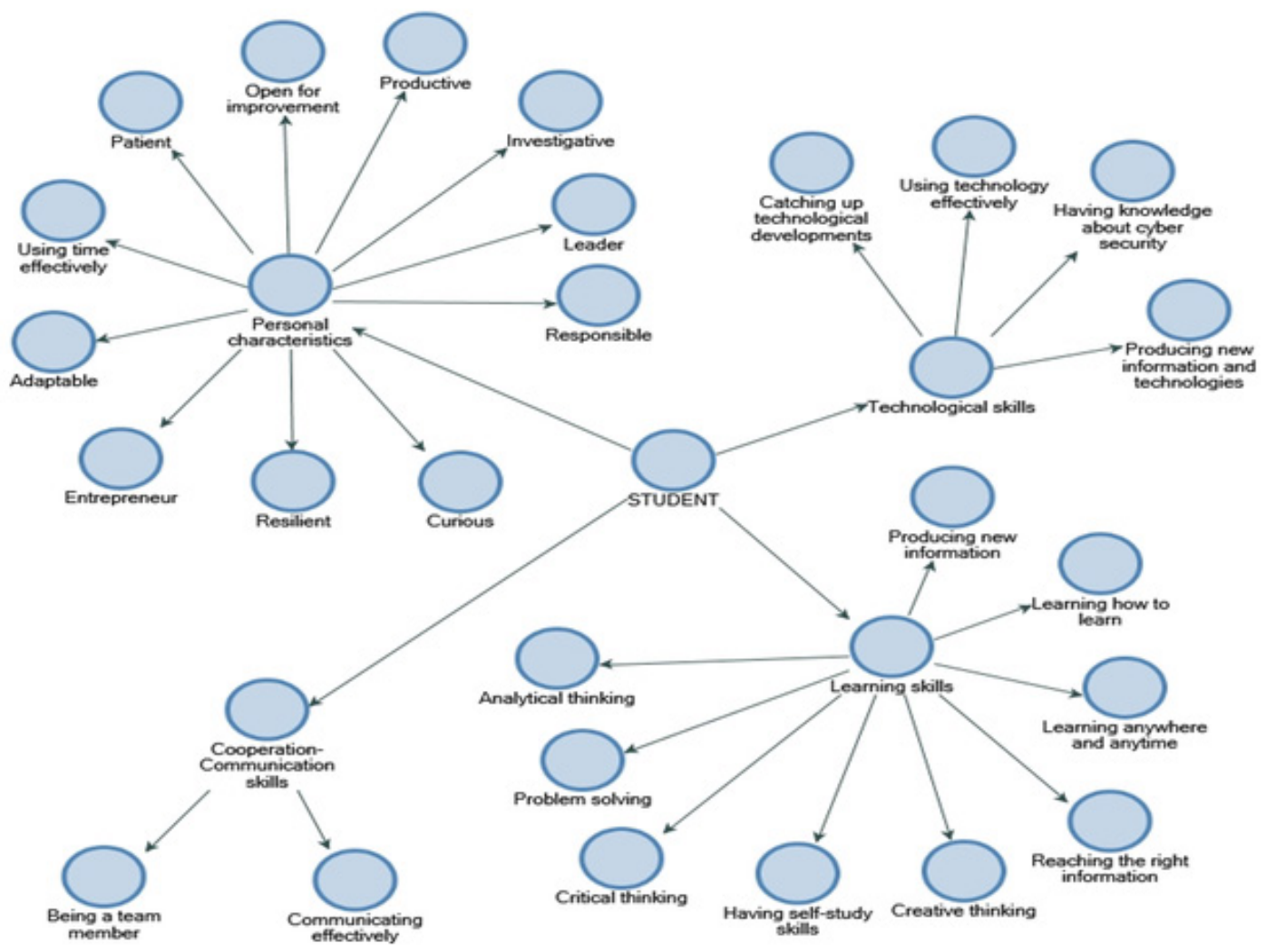

Figure 2. The qualifications expected from the student of Education 4.0 
When the findings presented in Figure 2 were examined, the features attributed to the students of Education 4.0 by the faculty members were grouped as cooperation-communication skills, technological skills, learning skills and personal characteristics. Collaboration-communication skills include to be a team member and to communicate well. Within the scope of technological skills, there are technological attitudes and behaviors such as having knowledge about cyber security, producing new information and technologies, using technology effectively and catching up technological developments. Learning skills include the skills that require the student to study, acquire knowledge and use cognitive competences. These include analytical thinking, problem solving, critical thinking, creative thinking, distinguishing between right and wrong information, having self-study skills, learning how to learn, generating new knowledge and learning anywhere and anytime. Within the scope of personal characteristics; being a researcher, entrepreneur, open to development, curious, productive, adaptable, responsible, resilient and leader were emphasized by participants. Some examples of faculty members' views on the qualifications expected from the student of Education 4.0 were as below:

"Skills demanded from students are changing. So, they need to be open to change and adaptable. They need to have skills such as problem solving, communicating well, especially virtual communication, managing big data, leading and using technology effectively. One of the most important skills demanded from students is questioning. Now, we need students who questions and criticize information in Education 4.0 instead of downloading it without questioning as in Education 1.0." (FM-1)

"The most important qualification of Education 4.0 demanding from students is self-study skill which includes starting to do something on their own and finishing it on their own. Along with that students need to have skills such as working collaboratively and managing time effectively." (FM-7) "In other words, the student should be investigative, open to collaborative works and prone to technology. I think there are not many students who are not capable of technology. Students should have at least information literacy at the basic level. Interpreting and analyzing knowledge are crucial skills for students. The most important things are interpreting, understanding and comprehending knowledge. Otherwise, raw data are no longer useful. Student should know how to reach knowledge very well." (FM-8)

"Using technology well can be a desired qualification for students of Education 4.0. In addition, the information has become the product which creating value added for developing countries. On the hand, information will be available by software and coding training. Therefore, students should have skills such as being investigative, problem-solving and creative thinking." (FM-10)

\section{The Qualifications Expected from the Teacher of Education 4.0}

The third sub-question of the study is related to the views of faculty members about the qualifications expected from the teacher of Education 4.0. For this sub-question, data were analyzed in line with the answers given by the faculty members to the interview questions and the findings were presented in Figure 3. 


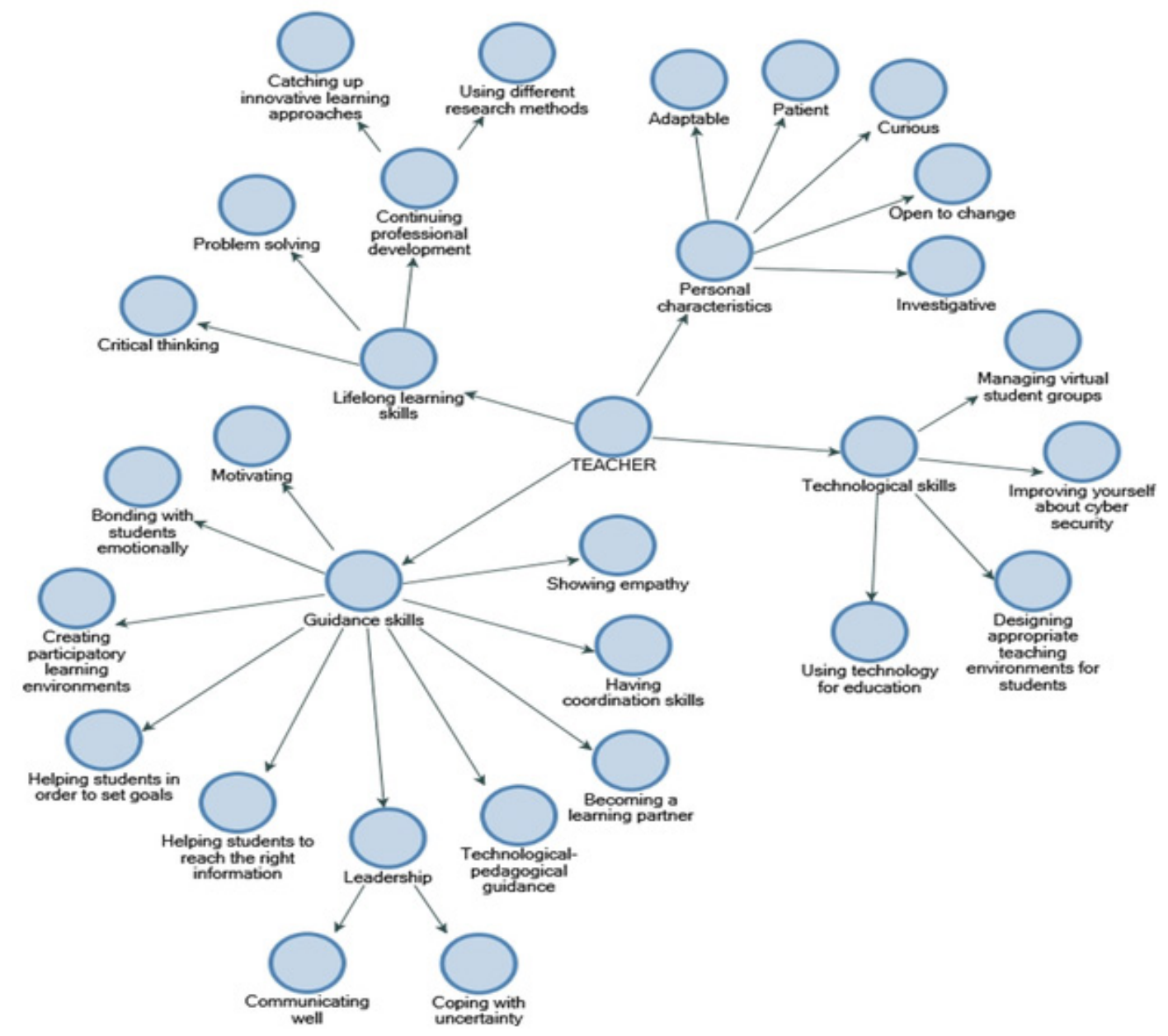

Figure 3. The qualifications expected from the teacher of Education 4.0

When the findings were examined in Figure 3, it was seen that qualifications describing teacher of Education 4.0 were categorized as technological skills, guidance skills, lifelong learning skills and personal characteristics. It was determined that the skills under the theme of technological skills showed similarities with the technological skills of the students. However, technological skills special for teacher of Education 4.0 were determined as managing virtual student groups and integrating technology with learning-teaching processes. Similar to the students, expected personal characteristics from the teacher of education 4.0 were determined as being curious, patient, open to change, adaptable and investigative. For the teacher of Education 4.0, lifelong learning skills were underlined. For this reason, lifelong learning skills for the teacher of Education 4.0, integrated with learning skills, was distinguished as following innovative learning approaches and sustaining continuous professional development. It was determined that the most crucial skills for teacher of Education 4.0 are guidance skills. In this context, guiding students technologically and pedagogically, bonding with students emotionally, coordinating, motivating, leading, creating a participatory learning environment, helping students to reach right information and helping students to set their goals are emphasized. Below are some of the views of faculty members on the qualifications expected from the teacher of Education 4.0:

"The role of teacher gains importance gradually in Education 4.0 because teacher is in mentor role now. Teacher needs to have self-improvement skills to guide students for dealing with big data and digital environment, learning how to learn and taking precautions for cyber-security. Teacher should also have skills such as problem solving, leadership, investigative and adaptable. The teacher should not be the person who directs the student and offers the information them, but the person should be who guides them and secures them in a virtual environment." (FM-1) 
"If you think it with a filter metaphor like a security wall or a virus detecting program, we always need teachers. So, the role of teacher will always be important because you can integrate artificial intelligence with information but you cannot integrate it with emotion or cognitive behaviors." (FM-6)

"If the teacher is a mentor, there will be no problem. Teacher should guide students both technologically and pedagogically. Teachers should not say students where they can find information from. For example, students do not know how to use an application. In this situation teacher should have technological competence about it." (FM-5)

"First of all, teachers have to be curious. I think curiosity is very important for teacher of Education 4.0. As I have said, thousands of applications exist. Teachers should search which application is the most suitable for their students. Teachers should wonder and investigate how they can teach better and how they can provide better learning environments for their students. Teachers have to be open to change." (FM-9)

\section{The Qualifications Expected From the School Manager of Education 4.0}

The last sub-question of the study is to describe the views of faculty members about the qualifications expected from the school manager of Education 4.0. For the last sub-question, data were analyzed in line with the answers given by the faculty members to the interview questions and the findings were presented in Figure 4.

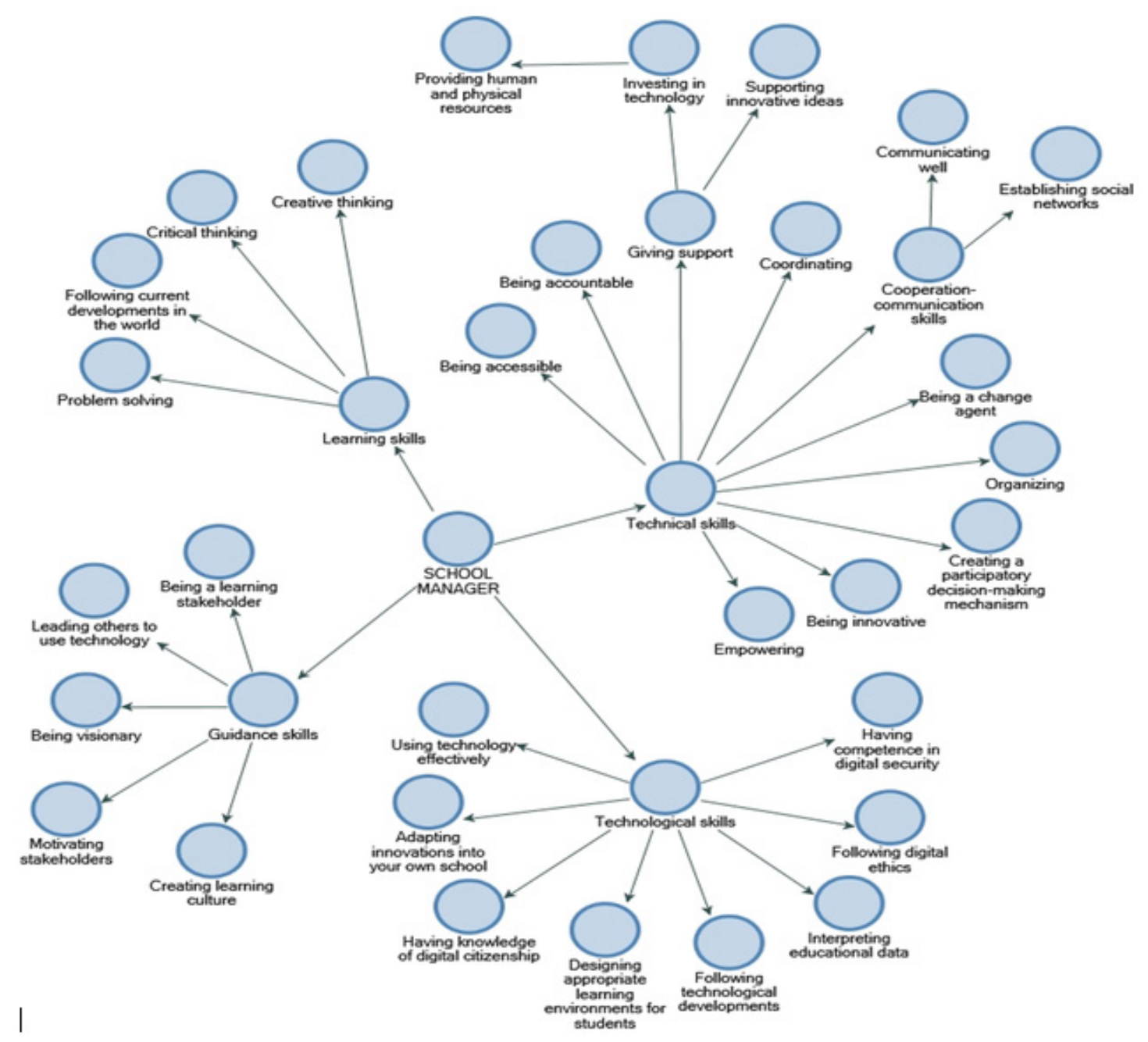

Figure 4. The qualifications expected from the school manager of Education 4.0 
When the findings were examined in Figure 4, it was inferred that the characteristics defining the school manager of 4.0 were grouped as guidance skills, technological skills, learning skills and technical skills. Within the scope of the guidance skills of the school manager, which are mostly related with the skills of providing technological guidance at the whole school level, motivating all stakeholders, being visionary, developing the learning culture and leading others to use technology were emphasized. As similar with technological skills for teacher of Education 4.0, school managers' technological skills were determined as following technological developments, using technology effectively, designing suitable learning environments for students and interpreting educational data. Differently, technological skills such as acquiring knowledge about digital citizenship, following to digital ethics and integrating innovations into their own schools were highlighted for school manager. It was found that learning skills like problem solving, critical thinking, creative thinking etc. are common for all school members examined in this study. However, it was found that skills that differentiate school manager from others are technical skills. The technical skills of school manager include their skills based on their expertise in school management. In this scope; the skills included being a change agent, coordinating, cooperating and communicating well, being accountable, being accessible, organizing, operating, empowering and providing support for participatory decision-making processes. Providing support differs from the traditional skills of the school manager in terms of giving chance to innovative ideas to enable technological development and innovation and investing in technology by providing the necessary human and material resources. Some of the views of faculty members on the qualifications expected from the school manager of Education 4.0 are presented below:

"...so you have to be a like a maestro to make teams work in coordination, in harmony. In this regard, leader should achieve the thing among teachers, society and students which a teacher tries to make in collaborative classroom environment." (FM-3)

"... besides I don't think that technical skills of school principals should be about Education 4.0 or industry, this field or school. I think school managers should be experts on school management. So, these skills are organizing, motivating, communicating, problem solving and creative thinking... "(FM-7)

".... The managers who are not aware of developments in the world and in their field, do not develop a vision in accordance with current developments and cannot put their in practice vision by working with their superiors in harmony seem to be useless in management position." (FM-4)

"School managers should be individuals who support teachers and their project-based assessments, make process assessments, provide physical equipment and technological tools and use technology very well. School managers' perspective about human relations can be understood from decision processes in the school. School managers should adopt a participatory decision-making mechanism which involves teachers, students, managers, parents and the environment." (FM-10)

\section{DISCUSSIONS AND CONCLUSION}

The literature has a consensus on the fact that Education 4.0 is the reflection of Industry 4.0 on education. It is called as educational reform which should meet the demands of Industry 4.0, especially workforce demand of it (Anggraeni, 2018, p.12-13; Hariharasudan \& Kot, 2018, p.1-2; Hussin, 2018, p.92). However, because Education 4.0 is something which does not exist actually for now, it is difficult to define and so to study it. The same problem is true for Industry 4.0. There are lots of conceptual studies in the literature but empirical studies are really rare (Wallner \& Wagner, 2016, p.157). This makes almost impossible to put Education 4.0 in practice before it was operationally defined and empirically researched. So, in this study it was aimed to determine the basic skills and qualifications of human components of Education 4.0 as student, teacher and school principal. The human side of Education 4.0 is so important that they are responsible for raising and being the workforce of Industry 4.0. To reach main aim of this study, members of Faculty of Education and Faculty of Open Education were interviewed. Firstly, the main qualifications of Education 4.0 according to participants were investigated. So, the main qualifications were determined as integration of digital technologies with education, seamless learning environments, individualized education, explorative education and life-long learning. The literature emphasizes usage of digital technologies in educational setting as the core qualification of Education 4.0 (Benesova \& Tupa, 2017, p.2196; Hariharasudan \& Kot, 2018, 
p.2; Wallner \& Wagner, 2016, p.156). These studies claim that the other qualifications of Education 4.0 lie in this core one (Hariharasudan and Kot, 2018, p.6). Integration of digital technologies with education is also accepted as one of the main prerequisites of innovation-based education, known as the education paradigm of $21^{\text {st }}$ century (Gulicheva et al., 2017, p. 131). This technology-based learning environments are described as "globalized, automatized, virtualized, networked and flexible" (Wallner \& Wagner, 2016, p.155). This is also valid for seamless learning environments which are especially emphasized from the aspect of learning anywhere and anytime (Anggreani, 2018, p.16; Wallner \& Wagner, 2016, p.157). Apart from technology integration and seamless learning environments, the other studies related to Education 4.0 describe its' main qualifications as similar to the findings of this study. For example, Fisk (2017) summarizes these qualifications under nine categories. These are diverse time and place, personalized learning, free choice, project-based education, field experience, data interpretation, different assessment types to test application of knowledge, students' involvement in curriculum development and lastly teachers as mentors (Hussin, 2018, p.92-93). Sadiyoko (2017) also summarizes characteristics of Education 4.0 under nine similar categories (Anggreani, 2018, p.15). This study's findings also include similar qualifications however assessment criterion and student involvement in curriculum development process are not mentioned by the participants of this study. On the other hand, they emphasized the importance of life-long learning. There are also studies which mention about the importance of life-long learning for Education 4.0 (Hariharasudan \& Kot, 2008, p.6; Wallner \& Wagner, 2016, p.155). So, to actualize Education 4.0 and to create the future by describing it, learning should get rid of the boundaries of traditional school walls. Besides, education should be accessible for anybody, at anytime and anywhere.

The second sub-question of the study aims to define qualifications of students needed for Education 4.0 from the views of participants. This can be accepted as one of the biggest issues discussed in the literature related to Education 4.0 since Education 4.0 is needed to raise human resources of Industry 4.0 (Benesova \& Tupa, 2017, p.2196; Wallner \& Wagner, 2016, p.157). So, defining qualifications of students mean defining the human resources that Industry 4.0 needs. In this study the main qualifications of students of Education 4.0 are determined under categories of technological skills, communication and collaboration skills, learning skills such as problem solving, analytical thinking or critical thinking etc. and personal qualifications such as being responsible, adaptable, resilient, researcher etc. Technological skills are mentioned most of the studies talking about students' skills in the related literature (Hariharasudan \& Kot, 2018, p.6; Hussin, 2018, p.93) because of technology-based nature of Education 4.0. However, studies generally discuss that even technological skills are pre-requisite for Education 4.0, they are already owned by students of 2010s who are called as Generation $\mathrm{Z}$ too. Generation $\mathrm{Z}$ students need collaborative and interactive learning environments, so they, themselves, also have such communication and collaboration skills (Hussin, 2018, p.93). Studies emphasize the importance of cognitive skills such as non-linear thinking and social skills such as being adaptable to intercultural learning environments, learning skills such as producing knowledge and engaging in life-long learning activities (Hariharasudan \& Kot, 2018, p.6; Wallner \& Wagner, 2016, p.155). Besides, Education 4.0 is related to skills such as autonomous learning, creative thinking, problem solving, critical thinking, having communication skills and being collaborative (Salmon, 2019, p.109). These skills prepare students to the real life and demands of Industry 4.0 (Hariharasudan \& Kot, 2018, p.6) since these ones make them valuable and indispensable resources for the organizations of future. Such skills mentioned in the literature and by the participants of this study also look like the skills called as $21^{\text {st }}$ century skills. $21^{\text {st }}$ century skills include cross-cultural understanding, learning and innovation skills such as critical thinking, problem solving, creative thinking etc., digital literacy skills such as media and information literacy etc., career and life skills such as being flexible, responsible, initiative and adaptable etc. (Larson \& Miller, 2011, p.122-123; Puncreobutr, 2016, p.94; Trilling \& Fadel, 2009; p.xxvi) These are soft skills which go beyond just having knowledge about something. They demand cognitive processing, producing knowledge and being adaptable since the main core of Industry 4.0 era is the change.

The third sub-question of the study aims to define qualifications of teachers needed for Education 4.0. In this study the main qualifications of teachers of Education 4.0 are determined under categories of technological skills, guidance skills, lifelong learning skills and personal characteristics such as being curious, patient, open to change, adaptable and investigative. Although these qualifications are similar with the qualifications expected from the students of Education 4.0, it was determined that guidance skills are specific to teacher 
of Education 4.0. Kilic (2018) emphasized that mentor teacher figure will be important instead of the classical authoritarian teacher figure in Education 4.0. The main reason why teachers' guidance skills gain importance is that the amount information which students can access is plenty. So, it is stated that the teachers of Education 4.0 should be a guide for students to access and benefit from this new information rather than being a subject matter specialist (Wallner, \& Wagner, 2016, p.157). Thus, it will be possible for students to distinguish right and wrong information from unlimited information sources. It is also emphasized that teacher of education 4.0 should guide students to set their own study goals. With this guidance, students can focus on their abilities and goals in life and teachers can offer them individualized education opportunities which is highlighted in the qualifications of Education 4.0 (Wallner, \& Wagner, 2016, p.156). Abersek and Flogie (2018) also point out that individualized education in Education 4.0 can be achieved through the use of technology and an innovative pedagogy approach and each student should be guided individually. Consequently, it can be inferred that one of the most important skills expected from the teacher of Education 4.0 are guidance skills. Another qualifications expected from the teacher of Education 4.0 was found as lifelong learning skills in the study. In the 21st century, teachers' lifelong learning skills have become important as teachers play a role in that not only transmitting the information, but also in teaching how to access them. Teachers' lifelong learning means that teachers are open to learning throughout their lives and know how to learn (Yaman \& Kilic, 2015, p.1555). One of the main features of Education 4.0 is the implementating a learning type which emphasizes learning anywhere and anytime, such as lifelong learning, e-learning, and online learning (Kilic, 2018). In this sense, lifelong learning, important for all education stakeholders, was emphasized mostly for teachers to adapt themselves to the changing and dynamic nature of knowledge. It is also expected that teacher of Education 4.0 is competent in the use of technology and to integrate these technological skills with the educational processes. According to Cagiltay et al. (2007, p.209), the reasons that trigger the use of technology in classrooms are the students' tendency towards technology and students' demands and expectations of the use of instructional technologies in the courses. The fact that 21 st century students belong to generation $Z$, which was born and raised in a digital age (Prensky, 2001, p.1), can be evaluated as the underlying reason for these demands. Education 4.0 is characterized as an educational approach aimed at improving digital technological competencies across all levels and enhancing the use of digital technologies for teaching and learning process. In this context, the emphasis on having digitally competent teachers to achieve Education 4.0 in the literature (Hariharasudan \& Kot, 2018, p.6) supports the findings of this research. Lastly, it can be said that teachers' integration of pedagogy with technology in the teaching-learning process is one of the prerequisites of Education 4.0.

The last sub-question of the study aims to define the qualifications of school managers needed for Education 4.0. In this study the main qualifications of school managers of Education 4.0 are determined under categories of guidance skills, technological skills, learning skills and technical skills. In this study, it was emphasized that school managers of Education 4.0 should have the learning skills such as creative thinking, problem solving, critical thinking and catching up technological developments. In the literature, it is stated that the most valuable skills of Education 4.0 are creativity, critical thinking, sensitive communication and collaboration skills (Salmon, 2019, p.109). Puncreobutr (2016) states that Education 4.0 can be defined with 21 st Century skills. In this context, Education 4.0 requires skills like problem solving, creative thinking, critical thinking, information and media literacy etc. Therefore, it can be said that these skills, which are important for all of the education stakeholders, are also considered as a requirement for the school managers. Another qualifications expected from the school managers of Education 4.0 are technological skills, which teachers and students should have. Because Education 4.0 is defined as a technology-based learning and teaching method (Hariharasudan \& Kot, 2018, p.6), it is required all education stakeholders having technological skills in Education 4.0. For this reason, it can be said that it is an expected result that the school managers of Education 4.0 should use technology effectively and follow technological developments. However, there are different expectations under this category from school managers compared to other stakeholders. The concept of technological leadership defined as being responsible for improving the interface between the human and the information technology components (Scanga, 2004, p.5), has become one of the emphasized leadership styles of 21st century. School managers are responsible for developing leadership and management strategies for the integration of technology into schools (Weng \& Tang, 2014, p.93). In short, school managers are responsible for the transfer and efficient use of computers and related technologies in the school (Turan, 2002, p.271). For this reason, it can be said that to have knowledge and 
competence in digital ethics, digital citizenship and digital security issues and to lead other stakeholders of the school are expected from school managers of Education 4.0 as technological skills. Another key element of Education 4.0 is the usage of learning analytics to predict students' future performance and to maintain their continuous improvement (Ciolacu, Tehrani, Beer \& Popp, 2017, p.439). In this sense, school managers' ability to interpret educational data can be evaluated as a skill that will facilitate the transition of schools to Education 4.0. Another mentioned skill for school managers of Education 4.0 is guidance skills. Puncreobutr (2016) states that the core of Education 4.0 is to guide students develop their skills to use new technologies. It can be inferred that there is a guidance and mentorship perspective on the basis of Education 4.0. So, it can be said that guidance skills are important for both teachers and school managers in Education 4.0 model. However, the guidance skills of the Education 4.0 managers differ from those of the teachers' since they refer to guidance throughout the school such as placing learning culture at school, directing school stakeholders on technology, and motivating school stakeholders. In the literature, technical knowledge and skills in task-related activity areas are called technical competences. All of the technical knowledge and competencies related to the methods, techniques and processes to be used to fulfill the task requirements constitute the technical activities of that task (Basar, 1993, p.66-67). In this study, it was determined that, unlike other stakeholders, school managers of Education 4.0 are expected to have technical knowledge and skills related to school management. It was emphasized that school managers of Education 4.0 should have skills such as organizing, coordinating, empowering school personnel, adopting a participatory decision-making mechanism in the context of technical skills. Abersek and Flogie (2017) also point out that, human skills and decentralized decisions such as making informed decisions and solving urgent problems in a short time will gain importance in the education systems adapting Education 4.0. So, it can be said that the school managers of Education 4.0 will come to the forefront with their decision-making mechanisms applied in their schools. In addition, since Education 4.0 is a technology-intensive education approach, some questions as how much the school managers of Education 4.0 invest in technology, how they give importance to improving the technological skills of the human resources in the school and how much they support innovative ideas will be important.

As a result of this study in which the basic features of Education 4.0 are examined in the context of human resources; to implement Education 4.0, the necessity of integration of technology into education is emphasized. So, importance of realizing digital transformation in education to ensure the integration of education with technology for Education 4.0 is understood. In addition, to achieve Education 4.0, it can be suggested to conduct research on the content, objectives, learning experiences and assessment elements of Education 4.0's curriculum. Also, it can be suggested to conduct studies to examine the readiness levels of Turkish Education System for Education 4.0 within the context of the qualifications revealed in this study.

\section{BIODATA and CONTACT ADDRESSES of AUTHORS}

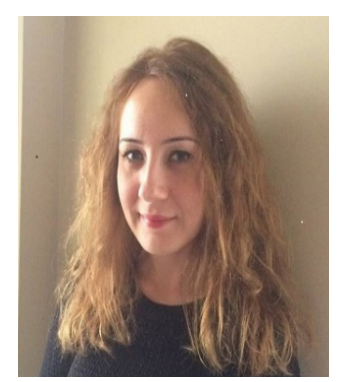

Beyza HIMMETOGLU has graduated from English Language Teaching, Faculty of Education, Cukurova University, Turkey in 2010. She has gained her master degree at Department of Educational Sciences, Faculty of Education, Anadolu University, 2014 on the relationships between conflict management styles of school administrators and school culture. She is a PhD student and works as a research assistant at Department of Educational Sciences, Faculty of Education, Anadolu University, Turkey. Her academic research interests are school culture, change management, organizational development, organizational adaptability, organizational memory and learning, organizational behaviors. She has published articles in internationally indexed journals, submitted to and presented paper at international meetings, conferences, seminars etc. She has contributed one international and three national research projects.

\section{Beyza HIMMETOGLU}

Faculty of Education

Address: Anadolu University, Education Faculty, Eskisehir, Turkey, Country

Phone: +90 2223350580

E-mail: beyzahimmetoglu@anadolu.edu.tr 


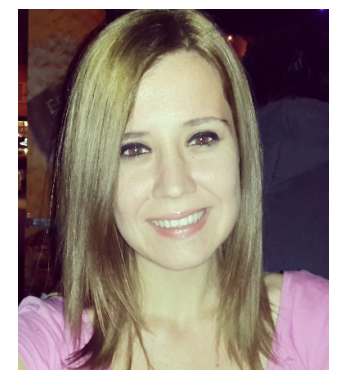

Damla AYDUG has graduated from Science Teaching, Faculty of Education, Middle East Technical University, Turkey in 2010. She has gained her master degree at Department of Educational Sciences, Faculty of Education, Anadolu University, 2014 on the relationships between organizational health and organizational trust at primary schools. She is a PhD student and works as a research assistant at Department of Educational Sciences, Faculty of Education, Anadolu University, Turkey. Her academic research interests are organizational health, organizational trust, school evaluation, organizational behaviors, organizational learning and forgetting and school development. She has published articles in internationally indexed journals, submitted to and presented paper at international meetings, conferences, seminars etc. She has contributed one international and three national research projects.

Damla AYDUG

Faculty of Education

Address: Anadolu University, Education Faculty, Eskisehir, Turkey, Country

Phone: +90 2223350580

E-mail: damlaaydug@anadolu.edu.tr

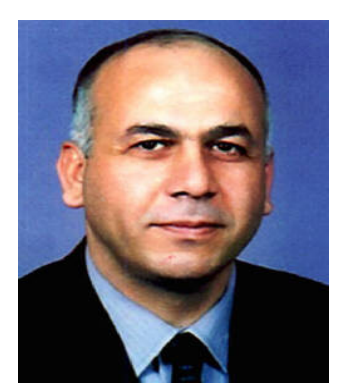

Dr. Coskun BAYRAK is a professor of Educational Administration at Faculty of Education, Anadolu University. Dr. Bayrak has gained his Ph.D. in Educational Administration department of Hacettepe University in 1990 with a thesis about organizational change in educational organizations. He has been working as a lecturer since 1996 at Anadolu University. He has become a professor in 2001. Some of his academic research interests are organizational change, leadership, conflict management, school development, human resources management, motivation and teacher education. He has participated in national and international projects especially on school leadership and school development and he has published more than 30 journal articles in national and international indexes. He has published book chapters, submitted and presented papers for international meetings and attended many conferences, seminars and etc.

Coskun BAYRAK

Faculty of Education

Address: Anadolu University, Education Faculty, Eskisehir, Turkey, Country

Phone: +90 2223350580

E-mail: cbayrak@anadolu.edu.tr

\section{REFERENCES}

Abersek, B., \& Flogie, A. (2017). Evolution of competences for new era or education 4.0. In XXV Conference of Czech Educational Research Association (CERA/CAPV)"Impact of Technologies in the Sphere of Education and Educational Research", Czech.

Anggraeni, C. W. (2018). Promoting Education 4.0 in English for survival class: What are the challenges?. Metathesis: Journal of English Language, Literature, and Teaching, 2(1), 12-24.

Ballantyne, N., Wong, Y. C. ve Morgan, G. (2017). Human services and the fourth industrial revolution: From husITa 1987 to husITa 2016. Journal of Technology in Human Services, 35(1), 1-7.

Basar, H. (1993). Egitim denetcisi: Roller, yeterlikleri, secilmesi, yetistirilmesi (2. Baski). Ankara: PEGEM.

Benesova, A., \& Tupa, J. (2017). Requirements for education and qualification of people in Industry 4.0. Procedia Manufacturing, 11, 2195-2202.

Blinder, A. P. (2006). Offshoring: The next industrial revolution?. Foreign Affairs, 85(2), 113-128. 
Bloem, J., Van Doorn, M., Duivestein, P., Excoffier, D., Maas, R. \& Van Ommeren, E. (2014). The fourth industrial revolution. Things to tighten the link between IT and OT. SOGETI: VINT Research Report 3 of 4 .

Buyukozturk, S., Cakmak, E.K., Akgun, O.E., Karadeniz, S., Demirel, F. (2011). Bilimsel arastirma yontemleri (10. Baski). Ankara: Pegem Akademi.

Ciolacu, M., Tehrani, A. F., Beer, R., \& Popp, H. (2017). Education 4.0-Fostering student's performance with machine learning methods. In 2017 IEEE 23rd International Symposium for Design and Technology in Electronic Packaging (SIITME) (pp. 438-443). IEEE.

Collins, A. \& Halverson, R. (2010). The second educational revolution: Rethinking education in the age of technology. Journal of Computer Assisted Learning, 26(1), 18-27.

Cagiltay, K., Yildirim, S., Aslan, I., Gok, A., Gurel, G., Karakus, T., Saltan, F., Uzun, E., Ulgen, E., \& Yildiz, I. (2007). Ogretim teknolojilerinin universitede kullanimina yonelik aliskanliklar ve beklentiler: Betimleyici bir calisma. Akademik Bilisim'07 - IX. Akademik Bilisim Konferansi Bildirileri, Kutahya, Dumlupinar Universitesi, 31 Ocak-2 Subat 2007.

Drath, R. \& Horch, A. (2014). Industrie 4.0: Hit or hype? [industry forum]. IEEE Industrial Electronics Magazine, 8(2), 56-58.

Galetta, A. (2013). Mastering the semi-structured interview and beyond: From research design to analysis and publication. New York, USA: New York University Press.

Garrison, D. R. \& Kanuka, H. (2004). Blended learning: Uncovering its transformative potential in higher education. The Internet and Higher Education, 7(2), 95-105.

Gogebakan-Yildiz, D., Kiyici, G. \& Altintas, G. (2016). Ters-yuz edilmis sinif modelinin ogretmen adaylarinin elestirileri ve gorusleri acisindan incelenmesi. Sakarya University Journal of Education 6(3), 186-200.

Gulicheva, E., Lisin, E., Osipova, M., \& Khabdullin, A. (2017). Leading factors in the formation of innovative education environment. Journal of International Studies Vol, 10(2), 129-137.

Hariharasudan, A., \& Kot, S. (2018). A scoping review on Digital English and Education 4.0 for Industry 4.0. Social Sciences, 7(11), 227, 1-13.

Harkins, A. M. (2008). Leapfrog principles and practices: Core components of education 3.0 and 4.0. Futures Research Quarterly, 24(1), 19-31.

Hermann, M., Pentek, T. ve Otto, B. (2016). Design principles for industrie 4.0 scenariop. 49th Hawaii International Conference on System Sciences (p. 3928-3937). IEEE.

Hussin, A. A. (2018). Education 4.0 made simple: Ideas for teaching. International Journal of Education and Literacy Studies, 6(3), 92-98.

Kilic, T. (2018). Hezarfen egitim modeli. Istanbul: AZ Kitap.

Krefting, L. (1991). Rigor in qualitative research: The assessment of trustworthiness. American Journal of Occupational Therapy, 45, 214-222.

Larson, L. C., \& Miller, T. N. (2011). 21st century skills: Prepare students for the future. Kappa Delta Pi Record, 47(3), 121-123.

McComas, W. F. (Ed.). (2014). The language of science education: An expanded glossary of key terms and concepts in science teaching and learning. Rotterdam, The Netherlands: Sense Publisher.

Merriam, P. B. (2009). Qualitative research: A guide to design and implementation (2nd Ed.). San Francisco: Jossey-Bass.

Miles, B. M. \& Huberman, A. M. (1994). Qualitative data analysis: An extended sourcebook (2nd Edition). Thousand Oaks, California: SAGE Publications.

Moravec, J. W. (2008). Moving beyond Education 2.0. https://www2.educationfutures.com/blog/2008/02/ moving-beyond-education-20/ adresinden 15.04.2020 tarihinde edinilmistir. 
Moravec, J.W. (2013). Rethinking human capital development in Knowmad Society, J.W. Moravec (Ed.), Knowmad society (31-56) icinde, Minneapolis, MN: Education Futurep.

Partnership for 21st Century Skills-P21. (2009). P21 framework definitions. https://files.eric.ed.gov/fulltext/ ED519462.pdf adresinden 15.04.2020 tarihinde edinilmistir.

Patton, M. Q. (2014). Nitel arastirma ve degerlendirme yontemleri (3. Baskidan Ceviri). (Cev. Ed. M. Butun ve P.B. Demir). Ankara: Pegem akademi.

Peters, M. A. (2017). Technological unemployment: Educating for the fourth industrial revolution. Journal of Self-Governance and Management Economics, 5(1), 32-41.

Prensky, M. (2001). Digital Natives, Digital Immigrants Part 1. On the Horizon, 9(5), 1-6.

Puncreobutr, V. (2016). Education 4.0: New challenge of learning. St. Theresa Journal of Humanities and Social Sciences, 2(2), 92-97.

Salmon, G. (2019). May the fourth be with you: Creating Education 4.0. Journal of Learning for DevelopmentJL4D, 6(2), 95-115.

Scanga, D. (2004). Technology competencies for school administrators. Unpublished Dissertation of Doctor of Philosophy. Florida, USA: South Florida University.

Sendov, B. (1987). Education for an information age. Impact of Science on Society, 37(2), 193-201.

Trilling, B. \& Fadel, C. (2009). $21^{\text {st }}$ century skills: Learning for life in our times. San Francisco, USA: John Wiley \& Sons, Inc.

Turan, S. (2002). Teknolojinin okul yonetiminde etkin kullaniminda egitim yoneticisinin rolu. Kuram ve Uygulamada Egitim Yonetimi, 30(30), 271-281.

Wallner, T. \& Wagner, G. (2016). Academic education 4.0. Proceedings of the international conference on education and new developments END 2016 icinde (pp. 155-159). Ljubljana, Slovenia, 12-14 Haziran 2016.

Weng, C. H. \& Tang, Y. (2014). The relationship between technology leadership strategies and effectiveness of school administration: An empirical study. Computers \& Education, 76, 91-107.

World Economic Forum. (2017). ASEAN 4.0: What does the Fourth Industrial Revolutaion mean for regional economic integration? https:/www.adb.org/publications/asean-fourth-industrialrevolution-regional-economic-integration adresinden 05.03.2018 tarihinde edinilmistir.

Yaman, F., \& Yazar, T. (2015). Ogretmenlerin yasam boyu ogrenme egilimlerinin incelenmesi: Diyarbakir ili ornegi. Kastamonu Egitim Dergisi, 23(4), 1553-1566.

Yildirim, A., Simsek, H. (2011). Sosyal bilimlerde nitel arastirma yontemleri (8. Tipki Basim). Ankara: Seckin Yayincilik.

Yildiz-Aybek, H. P. (2017). Universite 4.0'a gecis sureci: Kavramsal bir yaklasim. Acikogretim Uygulamalari ve Arastirmalari Dergisi, 3(2), 164-176.

Youngkin, C. A. (2014). The flipped classroom: practices and opportunities for health sciences librarians. Medical Reference Services Quarterly, 33(4), 367-374. 